\title{
Legal Protection for unregistered citizen at Healthcare and Social Security Agency (BPJS)
}

\author{
Andi Nur Awaliah Ramadhani ${ }^{1 *}$, Zulkifli Aspan ${ }^{1}$, Muh. Hasrul ${ }^{1}$ \\ ${ }^{1}$ Faculty of Law, Hasanuddin University, Indonesia \\ *Correspondence: anurulandi@gmail.com
}

\section{ARTICLE HISTORY}

Received: 27.10.2021

Accepted: 24.12.2021

Published: 27.12.2021

\section{ARTICLE LICENCE}

Copyright (C) 2021 The Author(s): This is an open-access article distributed under the terms of the Creative Commons Attribution

ShareAlike 4.0 International (CC BY-SA 4.0)

\begin{abstract}
Despite the reality that the JKN program is necessary for all Indonesian residents, there are still individuals who have not enrolled as JKN members. The purpose of this research is to evaluate and explain the application of individual health services and the government's impediments to citizens receiving legal protection under the BPJS health health social security system. The research approach adopted is one of normative legal research. A descriptive legal approach was adopted in the assessment process. According to the findings of this study, the application of individual health services in the framework of legal protection for people who are not enrolled in the BPJS Health social security system is restricted to the supply of health facilities. The state does not offer legal protection in the form of duty for delivering health care, because individuals who are not enrolled as BPJS Health participants will be registered as general patients, requiring them to pay for treatments individually or through private insurance. While the idea of BPJS Health as given in the BPJS Law requires everyone to register for BPJS Health, BPJS Health still has several inadequacies, which causes some individuals to be hesitant and unwilling to register as BPJS Health participants. The government cannot claim that the lack of legal protection in health services is the responsibility of those who do not register as BPJS Health participants, because this is a result or implication of the numerous deficiencies in health services that continue to employ BPJS Health.
\end{abstract}

Keywords: Legal Protection; Citizen; BPJS

\section{Introduction}

Social security that enables individuals to grow is one of the fundamental rights proclaimed in the 1945 Constitution of the Republic of Indonesia (UUD NRI 1945) as the highestregulatory hierarchy. This is expressed in paragraph (3) of article $28 \mathrm{H}$, which states that everyone has the right to social security that enables his or her complete developmentasa dignified human being.

Furthermore, the development of the social security system has also been regulated in Article 34 paragraph (2) of the 1945 Constitution of the Republic of Indonesia. The State develops a social security system for all people and empowers the weak and incapable in accordance with human rights dignity.

The declaration of constitutional social security as a universal right is a response to the 1948 United Nations Declaration on Human Rights. Indonesia accepted the declaration, which establishes that everyone has the right to social security in the case of unemployment, disease, disability, inability to work, widowhood, or old age. In order to comply with the United Nations Declaration on Social Security Rights, ILO Convention No. 102 of 1952 suggested that all nations offer fundamental protection to all citizens (Tim Kecil Pokja, 2020). As part of the process of creating social security and following the mandate of the Republic of Indonesia's 1945 Constitution, Law No. the spirit of recognizing social security as a right of all people to receive a social "feeling of security" from birth to death. This is to ensure that the fundamental necessities of a decent existence are met and to enhance dignity in order to realize an Indonesian society that is prosperous, just, and prosperous(Sulastomo, 2011).

According to the requirements of Article 1 paragraph (1) of Law No. 40 of 2004 on the National Social Security System, Social Security is a kind of social protection designed to ensure thatall individuals may meet their fundamental necessities for a dignified existence (NKRI, 2004). Additionally, Article 1 paragraph (2) of the SJSN 
Law establishes that the Social Security System is a mechanism for the administration of social security programs by a number of social security administering organizations.

As a means of carrying out the mandate under Article 5 paragraph(1) of the SJSN Law, a Social Security Administering Agency was established pursuant to Law Number 24 of 2011 concerning the Social Security Administering Body (BPJS) in the hope that every resident can meet the basic needs of a decent life in the event of loss or reduced income due to illness, accident, or loss of employment. Regarding membership, the BPJS Law emphasizes the mandatory nature of participation in Article 4 letter $\mathrm{g}$, which is reinforced in Article 14 paragraph (1), which states that everyone, including foreigners who work in Indonesia for a minimum of six (six) months, is required to become a Social Security participant (NKRI, 2011).

Mandatory participation is a social security policy that compels all inhabitants to enroll in the program. In terms of membership, the Social Security Administering Body's involvement is separated into various components, namely:

a) Recipient of contribution help

b) Foreigners who have worked in Indonesia for at least six months

c) Worker

d) Employer

e) Each individual.

The explanation above states that contribution assistance is a reimbursementmade by the government to poor and underprivileged individuals whoparticipate in the social security program. Worker is defined as any person who works for a salary, wages, or other form of remuneration, employer is defined as an individual, entrepreneur, legal entity, or other entity that employs workers, or state administrators who employ civil servants by paying salaries, wages, or other forms of remuneration. Each person is defined under Article 16 paragraph (1) of the BPJS Law, which states:

Everyone who exceeds the conditions for participation in the social security program, save employers, employees, and beneficiaries of contribution assistance, is required to register himself and his family members as participants with BPJS in line with the social security program in effect.

According to the classification, everyone is required to engage in the guarantee program, even if they are not included in the classification but satisfy the conditions to participate in BPJS. BPJS, as the organizer of the social security program in the health sector, is one of five programs in the SJSN, namely health insurance, work accident insurance, pension insurance, and death insurance, all of which are listed in Law Number 40 of 2004 governing the SJSN. The National Health Insurance (JKN) program in Indonesia has been operational for nearly seven years as of 2021 , however several issues continue to cloud the program's execution, despite the fact that many individuals have benefited.

The central concerns troubling JKN, in general, are threefold: membership, service and availability of health care facilities, and finance. As a result, universal health care must be a shared commitmentin order for all residents to obtain complete health protection. However, as of October 31, 2019, statistics indicated that around 16.18 percent of the population, or over 40 million individuals, had notbeen registered as JKN-KIS members. Previously, complete health protection for the Indonesian people was scheduled to be implemented in 2019 with Universal Health Coverage (UHC), a program that guarantees individuals have access to health care withoutfacing financial hardship. This is facilitated by the availability of high-quality health care facilities (Riatkomo, 2018).

The JKN program began operations on January 1, 2014, and is required for all Indonesian nationals; nevertheless, some individuals have notenrolledas JKN members. The administration continues to make changes to the JKN implementation, however the issue of JKN participation persists. The community has cited numerous reasons for not registering to participate in the JKN-KIS (BPJS Kesehatan). According to the author's study, of the twenty respondents who have not or have not registered for BPJS Health, ten respondents stated that they lack the time necessary to manage the registration process. Additionally, five respondents have not enrolled or are not registered with BPJS Health because they do not wish to pay monthly fees, two respondents state that they cannot afford monthly charges, and three respondents express dissatisfaction with BPJS Health's health services (Ernawati \& Uswatul, 2019). 
In this regard, there is a risk that the application of citizen health services, particularly to citizens who are not registered as BPJS Health participants, will be inadequate. As a result, the application of citizen health services must be directed toward achieving the goal of legal protection for all citizens in general, and more specifically, to citizens who are not registered as BPJS Health participants, who will be disproportionately affected by the implementation. The absence of adequate health care undoubtedly has an effect on inhabitants, who are susceptible to a variety of illnesses. This is because, on average, this community group faces malnutrition, a lack of health awareness, unhealthy behaviors, a substandard living environment, unaffordable health care, and a lack of access to health information (Sudjadi \& Dkk, 2017). Service constraints imposed during the implementation of the national social security program impede the provision of health care to people in need. Whereas the execution of health services should meet minimal service standards, namely the provisions governing the nature and quality of basic services, which are considered government concerns and must adhere to each citizen's rights. The governmentis responsible for ensuring that every citizen has access to high-quality health care that is tailored to their specific requirements (Rusyad, 2018).

In this context, health services become a critical tool for achieving and enforcing human rights. The provision of public health services is certainly a component of protecting human rights, which is impacted by the availability of high-quality health care. As a result, the right to health services must be implemented to provide health care to people, particularly those who are not enrolled as BPJS Health participants.

Thus, the application of health services in the context of citizen legal protection serves a s both a framework and a tool for establishing Indonesia as a state of law that respects, upholds, and promotes human rights, one of the state of law's features. Hasrul (2017), claims that there are eleven fundamental elements of the rule of law or rechtsstaat that apply today, one of which is the preservation of human rights as a way of achieving the state's or Welfare Rechtsstaat's objectives.

Aminuddin IImar continued by stating that the rule of law is based on the provision of constitutional protection for human rights and legal safeguards for enforcing such rights through a fair procedure. Therefore, if a country's human rights are ignored or violated purposefully, and the resulting suffering cannot be dealt with equitably, the country cannotbe considered a real state of law (IImar, 2014).

The following account of the events surrounding the implementation of the JSN demonstrates that the national social security system, particularly social security, has not been implemented optimally as intended.

\section{Methodology}

The research approach chosen is one of normative legal research. The research strategy taken comprises a descriptive legislative approach in character, in that it emphasizes the depiction of current or historical occurrences. In general, normative legal study is synonymous with doctrinal or theoretical legal research. Thus, normative research focuses on written studies that employ secondary data sources such as statutes and regulations, court judgments, legal theory, and legal principles, and may take the shape of academic publications (doctrine) (Irwansyah, 2020). The data applied in this research is secondary data, which includes primary legal materials such as theories, norms, regulations, expert views, and secondary and tertiary legal resources pertinent to the topic.

\section{Result and Discussion}

Social security is a subset of the idea of social protection, which entails providing social security for individuals through periodic payments. Thus, social security is comprised of two components: social insurance and public assistance.

Since Indonesia's independence, the concept of social security has been mandated by Article 27 paragraph 2 of the 1945 Constitution of the Republic of Indonesia (UUD NRI 1945), which states that "Every citizen has the right to work and a decent living for humanity," as well as Article 34 paragraph (1) of the 1945 Constitution of the Republic of Indonesia, which states that "the state cares for the poor and neglected children." As described above, the meaning of Article 27 paragraph (2) of the 1945 Constitution of the Republic of Indonesia reflects the nuances of social security in terms of the right to work and obtain a decentlife through the payment of wages, welfare, and social security for work performed by state and local governmentemployees. private personnel. 
This is to maintain Indonesia out of a system of worker exploitation that favors exclusively company owners. Meanwhile, Article 34 paragraph (1) of the Republic of Indonesia's 1945 Constitution emphasizes the governments obligation as the state's representative to give social assistance to those who cannotafford it in the form of clothes, food, and housing. This is to ensure that no Indonesian is abandoned or starves to death, although the Indonesian state is endowed with natural riches and a tradition of mutual cooperation that dates back to the Indonesian nation's forefathers.

As a result, this representation is realized as the state's responsibility to support and care for its citizens, particularly those who lack enough economic ability. and boards for the disadvantaged. This is to ensure that no Indonesian is abandoned or starves to death, although the Indonesian state is endowed with natural riches and a tradition of cooperation that dates back to the Indonesian nation's forefathers. Thus, this representation is realized as the state's responsibility to preserve and care for its residents, particularly those who lack enough economic competence. and boards for disadvantaged individuals.

This is to ensure that no Indonesian is abandoned or starves to death, although the Indonesian state is endowed with natural riches and a tradition of mutual cooperation that dates back to the days of the Indonesian nation's forefathers. As a result, this representation is realized as the state's responsibility to sustain and care for its citizens, particularly those lacking economic capacity.

Additionally, the government emphasized the importance of social protection for its citizens by amending several articles, specifically the second amendment to the 1945 Constitution of the Republic of Indonesia, namely Article $28 \mathrm{H}$ paragraph (3), which states that "Everyone has the right to social security that enables his full selfdevelopmentas a dignified human being."Additionally, the fourth amendment to the Republic of Indonesia's 1945 Constitution, specifically Article 34 paragraph (2), states that "the state creates a social security system for all people and empowers the weak and unable in line with human dignity."

Besides being regulated by national law, social security is universally recognized by international countries through international agreements outlined in Article 22 and 25 of the 1948 United Nations Declaration on Human Rights (UDHR), as well as the ILO Convention No. 102 of 1952, which recommends that all countries provide a minimum level of protection to all workers. Indonesia has accepted and approved these provisions into national legal rules under the two (two) agreements stated above. Furthermore, at the 2001 MPR RI Annual Session, in line with the requirements of the 1945 Constitution of the Republic of Indonesia, the Universal Declaration of Human Rights, and the ILO Convention.

Following the mandate contained in the 1945 Constitution of the Republic of Indonesia, the Universal Declaration of Human Rights, the ILO Convention, and MPR Decree Number X/MPR/2001, the government enacted Law Number 40 of 2004 concerning the National Social Security System (SJSN Law), which aims to ensure that each participant and/or family member receives the basic necessities of a decent life. According to the requirements of Article 1 paragraph 1 of the SJSN Law, "social security is a type of social protection designed to ensure that all individuals may satisfy their fundamental necessities for a decent existence." Techniques for achieving social security.

According to Article 18 of the SJSN Law, one of the social security programs is health insurance. National health insurance is managed following social insurance principles and the notion of equality. The implementation of health insurance based on social insurance principles entails the following:

a) mutual cooperation between the rich and the poor, the healthy and the sick, the young and the old, and the high and low risk;

b) mandatory and non-selective participation;

c) contribution based on percentage of wages/income

d) non-profit.

Meanwhile, a health insurance system based on the equity principle ensures that members have equal access to treatments based on their medical requirements, regardless of the amount of payments made. The social security system has been essentially in place since the Republic of Indonesia gained independence before the Dutch colonial period. According to the history of social security in Indonesia, particularly concerning health 
insurance, efforts to assure the community's demand for health care, particularly for civil workers and their families, resumed in 1949, following the Dutch government's declaration of sovereignty. GA Siwabessy offered a concept to quickly create a national health insurance scheme, which was implemented in several developed and fast growing nations at the time (Humas BPJS Kesehatan, 2013).

At the time, the new health insurance coverage was restricted to public workers and their dependents. However, GA Siwabessy thinks that one day, the climax of the Indonesian people's health growth would be reached by establishing a system capable of ensuring the health of all residents. Therefore, in 1968, the Governmentissued Minister of Health Regulation No. 1 of 1968, creating the Health Maintenance Fund Organizing Agency (BPDPK) responsible for regulating health care for state employees, pension beneficiaries, and their dependents.

Several years later, the Government enacted Government Regulation No. 22 of 1984 on Health Care for Civil Servants, Pensioners, and Their Family Members and Government Regulation No. 23 of 1984 on Public Company (PERUM) Husada Bhakti. Additionally, the BPDPK transitioned from a Ministry of Health agency to a BUMN, called PERUM HUSADA BHAKTI (PHB), which offers health insurance to public servants, retired civil servants, veterans, and pioneers of independence, as well as their family members. Then, in 1992, according to Government Regulation No. 6 of 1992, PHB changed its name to PT Askes (Persero). Through the Commercial Askes initiative, PT Askes (Persero) began reaching out to BUMN workers. Then, in January 2005, the government entrusted PT Askes (Persero) to implement the health insurance program for the poor (PJKMM), dubbed the ASKESKIN program, with a target population of 60 million poor and underprivileged people whose contributions are covered by the Central Government. Additionally, PT Askes (Persero) established the General Public Health Insurance Program (PJKMU), which is designed for those who have not been able to obtain health coverage through Jamkesmas, Social Askes, or private insurance. Until then, more than 200 regencies/cities or 6.4 million people have joined the PJKMU. PJKMU is a regional health insurance company (Jamkesda) that is managed by PT Askes (Persero) (Humas BPJS Kesehatan, 2013).

According to Article 5 paragraph (3) letter d of the SJSN Law, PT Askes (Persero) is designated as a social security administering body that administers social security in the health insurance sector. However, a few years later, with the introduction of PT Askes' (Persero) health insurance scheme, the path toward expanded health coverage became more transparent with the passage of Law No. 24 of 2011 concerning the Social Security Administering Body (UU BPJS). The BPJS Law's course also requires the government to establish a social security administering organization in the health sector, dubbed "BPJS Kesehatan," on January 1, 2014, as specified in Article 60 paragraph (1) of the BPJS Law. As a result, PT Askes (Persero) was renamed BPJS Health on January 1,2014 . Following the formation and operation of BPJS Kesehatan, the company has become the exclusive supplier of health insurance in Indonesia, covering both the general public and civil workers, members of the Indonesian Armed Forces (TNI), and members of the Indonesian National Police. This is consistent with the stipulations of Article 60 paragraph (2) of the BPJS Law, which states:

"Since the operation of BPJS Health as referred to in paragraph (1):

a. The Ministry of Health no longer administers the public health insurance program;

b. The Ministry of Defence, the Indonesian National Armed Forces, and the Indonesian National Police no longer provide health service programs for their participants, except for certain health services related to their operational activities as specified by Presidential Regulation; and

c. PT Jamsostek (Persero) no longer operates a health care insurance program.

BPJS Kesehatan was founded primarily to carry out its primary duty to organize a health insurance scheme. BPJS Health is responsible for the administration of the health insurance program, which includes the following responsibilities:

1) Conducting and/or accepting participant registration;

2) Collecting contributions from participants and employers;

3) Receiving Government Contribution Assistance;

4) Managing Social Security Funds for the benefit of Participants;

5) Collecting and managing data on Social Security program participants; 
6) Paying benefits and/or financing health care services following the Social Security program's provisions;

7) Providing information to Participants and the general public about the Social Security program's implementation.

In realizing these functions and duties, BPJS Kesehatan has the authority to:

1) Collecting dues payment;

2) Placing Social Security Funds for short-term and long-term investments by considering aspects of liquidity, solvency, prudence, security of funds, and adequate returns;

3) Supervise and examine the compliance of Participants and Employers in fulfilling their obligations following the provisions of the national social security laws and regulations;

4) Agree with health facilities regarding the amount of payment for health facilities that refers to the standard tariff set by the Government;

5) Make or terminate an employment contract with a health facility;

6) Imposing administrative sanctions on Participants or Employers who do not fulfill their obligations;

7) Report the Employer to the competent authority regarding his non-compliance in paying Contributions or in fulfilling other obligations following the provisions of laws and regulations; and

8) Cooperating with other parties in the context of administering the Social Security program.

The implementation of the health insurance program by BPJS Health is carried out with the principles based on Article 4 of the BPJS Law, namely as follows:

a) Mutual cooperation

Mutual cooperation is the notion of Participants sharing the burden of Social Security expenses, which is accomplished by each Participant's duty to pay Contributions based on their Salary, Wage, or Income.

b) Non-profit

The non-profit concept is a company management approach that places a premium on the utilization of revenues from the creation of funds to maximize benefit to all Participants.

c) Openness

Transparency is the principle of allowing each Participant access to comprehensive, accurate, and transparentinformation.

d) Caution

The precautionary principle is the practice of prudently, completely, safely, and orderly management of finances.

e) Accountability

Accountability refers to the idea of accurate and accountable program execution and financial management

f) Portability

The principle of portability is delivering continuing benefits regardless of whether the Participant changes employmentor relocates inside the Unitary State of the Republic of Indonesia.

g) Participation is mandatory

The idea of obligatory participation is a progressive requirement that all inhabitants become Social Security Participants.

h) Trust fund 
The trust fund's underlying premise is that contributions and earnings from their development are deposited money from participants to be used to the greatest extent feasible for the benefit of social security participants. Thus, the Social Security Fund's earnings are fully directed toward program improvement and the maximum possible benefit to Participants.

The health insurance program organized by BPJS Kesehatan is conceptually distinct from the previous health insurance program conducted by PT Askes (Persero) and many other social security programs held since the Republic of Indonesia's independence. This is demonstrated by the requirements of Article 14 of the BPJS Law, which states that "Everyone, including foreigners who work in Indonesia for a minimum of six (six) months, shall enroll in the social security system.

Through the BPJS Health health insurance scheme, these requirements imply that health services in Indonesia have been generalized. BPJS Health now administers indonesia's health insurance program via a single door, namely the National Health Insurance Program-Healthy Indonesia Card (JKN-KIS). JKN-KIS is a conceptin which the state is present to ensure that all Indonesians have access to comprehensive, fair, and equitable health insurance.

The requirementfor every Indonesian citizen to register as a BPJS Health participant, as outlined in Article 14 of the BPJS Law, undoubtedly creates a distinct legal implication in health services, as it frequently results in complications during the administration of the BPJS Health health insurance program in Indonesia. Furthermore, numerous issues that arise in health services, most notably in this research, are connected to numerous public complaints about hospitals providing substandard care to patients who utilize the BPJS Health program. These accusations created havoc and instability in the neighborhood, making some residents hesitant to enroll in and use the BPJS Health program when they required health care. This is because of the issues that have arisen due to health services utilizing BPJS Health, resulting in a low degree of confidence. Indeed, the public has been asked to register as BPJS Health participants, expecting that health services will be delivered equally to all Indonesian residents through a payment system based on participants' periodic payments.

Due to public skepticism of hospital services that are less than optimum for patients who utilize BPJS Health, some people do not register with BPJS Health, even though every Indonesian citizen must be registered with BPJS Health under Article 14 of the BPJS Law. In essence, providing health care is not a community commitment; it is a governmentobligation, and it is everyone's right to acquire health services. The right to health care is a fundamental right that all people, particularly Indonesian nationals, have. This is following Article 34 paragraph (3) of the Republic of Indonesia's 1945 Constitution, which states that "the State is responsible for providing adequate health care and public service facilities."

According to this description, the author performed research in this study to identify and characterize the application of individual health services in the framework of legal protection for people who have not registered or are not enrolled in the BPJS Health health social security system. The authors conducted interviews with officials at Labuang Baji Hospital in Makassar City for their study. The following are the results of the author's interview on health services at Labuang Baji Hospital in Makassar City:

1. Makassar's Labuang Baji Hospital serves patients who are not registered with BPJS Kesehatan under the category of general patients.

2. Health services for those who are not registered with BPJS at Labuang Baji Hospital Makassar are following regular patientservice procedures

3. There is no difference in elements of public health services that are registered with BPJS and those who are not registered with BPJS, because those who are not registered with BPJS Health will be serviced as general patients. Maybe the difference in service is just in terms of data validation such that patients who utilize BPJS Health must queue to validate the data first, while ordinary users do not queue and may be treated instantly.

4. So far, there has never been a complaint or protest from the public due to not registered services with BPJS Kesehatan, because patients who are not registered with BPJS Kesehatan are included as general patients.

5. There is a difference in costs that must be incurred by people who are registered with BPJS and those who are not registered with BPJS Health, namely BPJS Health patients, no fees are charged to patients, while for patients who are not registered with BPJS Health, fees are charged according to the health services provided. 
6. The sorts of health services offered by the Labuang baji hospital at presentmoment include BPJS Health Jamkesda and Jamkesmas are no longer available since they have been moved to BPJS Health. likewise for other health insurance schemes that are supplied are insurance from private parties such as Mandiri Inhealth.

In addition to Labuang Baji Hospital Makassar, the author conducted interviews with hospital personnel or employees at Haji Hospital Makassar City to supplement the data collection and analysis. The following are the findings of the author's investigation at Makassar's Haji Hospital:

a) Through general patient care, Haji Makassar Hospital supports patients who are not registered with BPJS Kesehatan.

b) In general, health services at Haji Makassar Hospital are the same for individuals who are not enrolled with BPJS Health and those who are. However, the distinction is minor, with BPJS Health patients requiring extra documentation, namely BPJS Health cards, at the time of administration, whereas ordinary patients do not exist.

c) There is a difference in the pricing of health services at the Haji Makassar Hospital for patients enrolled with BPJS Health and general patients, with individuals registered with BPJS Health incurring no charge and general patients incurring a charge.

d) Only BPJS Health and Mandiri Inhealth insurance are accepted by Haji Makassar Hospital.

e) The method for admitting patients who are not registered with BPJS Kesehatan is identical to the procedure for accepting registered patients.

Based on the information gathered by the author at Labuang Baji Hospital Makassar and Haji Makassar Hospital, the following author analyzes the implementation of individual health services in the context of legal protection for citizens who have not enrolled in the BPJS Health social security system. The author's study of the implementation of individual health services in the framework of legal protection for citizens who are notenrolled in the BPJS Health social security system, particularly atLabuang Baji Hospital Makassar and Makassar HajiHospital, is as follows:

Analysis of the data collected by the author at Labuang Baji Hospital Makassar and Haji Makassar Hospital, the following author analyzes the implementation of individual health services in the context of legal protection for citizens who have not enrolled in the BPJS Health social security system. The author's study of the implementation of individual health services in the framework of legal protection for citizens who are notenrolled in the BPJS Health social security system, particularly at Labuang Baji Hospital Makassar and Makassar Haji Hospital, is as follows:

a. According to the author's research, the application of health services by Labuang Baji Hospital Makassar and Makassar Haji Hospital, particularly for people who are not registered with BPJS Kesehatan, is considered a health service with the category of general patients, which means that these patients pay regardless of the health facilities used at the hospital. Thus, everything that occurs during the patient's usage of these health facilities is entirely the patient's duty, as the legal connection that occurs during the health service is solely between the patientand the hospital (health facility).

b. According to the author, the government's legal protection of health services, particularly those not registered with BPJS Kesehatan, is limited to the provision of health facilities, as mandated by Article $28 \mathrm{H}$ paragraph (1) of the 1945 Constitution of the Republic of Indonesia, which states that "Everyone has the right to live physically and mentally prosperous, to have a place to live, and to obtain a good and healthy living environment, and to have the right..." Additionally, Article 34 paragraph (3) of the Republic of Indonesia's 1945 Constitution states that "the State is responsible for the provision of adequate health and public service facilities." Therefore, the implemented health services only give legal protection to citizens who are not enrolled with BPJS Kesehatan in providing health services.

c. In theory, the state has attempted to ensure legal protection for all citizens by establishing a national social security system, namely BPJS Health. However, the present idea of BPJS Health has several flaws, which causes some people to be cautious and unwilling to enroll in BPJS Health. While every Indonesian citizen and even foreigners who work in Indonesia for a minimum of six months are obliged to register for BPJS Health under Article 14 of the BPJS Law, the public cannot be compelled to register as a BPJS Health participant. 
d. BPJS conceptis, of all, to carry out the mandate of Article $28 \mathrm{H}$ paragraph (3) of the 1945 Constitution of the Republic of Indonesia, which states that "Everyone has the right to social security that enables his or her complete developmentas a dignified human being."And according to Article 34 paragraph (2) of the Republic of Indonesia's 1945 Constitution, "the state builds a social security system for all citizens and empowers the weak and unable in line with human dignity." While BPJS Kesehatan has carried out health administrati on on a national scale structurally and functionally, some people remain unregistered as BPJS Health participants for various reasons, including inability to pay premiums and administrative management difficulties, poor health services, and other factors that require BPJS Health to improve. The government cannotgetaway with not registering the community for BPJS Health, because if the community is not registered, it must bear the cost of health services independently, which means that the state is not fulfilling its role of providing social security in the form of adequate health insurance to the public. Of course, the government cannot shield it from the public's responsibility for failing to register as BPJS Health participants, since this is also a result or implication of the numerous problems that continue to exist in health services that employ BPJS Health.

e. Legal protection should be able to portray the law as an essential instrument in social life, becoming the principal weapon of the state in controlling the life of the country and state. The interests of the society are so diverse and varied that the state must be there to govern it in such a way as to establish a harmony. This is also underlined by Satjipto Rahardjo who claimed that these interests must be handled in such a way that it is feasible to minimize conflicts and waste. According to Satjipto Rahardjo, legal protection is to offer protection for human rights that are injured by others and that protection is given to the community so that all rights granted by law can be enjoyed. The fundamental goal of law as a forum that protects human interests is to produce an orderly and orderly social order so that it is hoped that individual lives in society may be fulfilled in a balanced fashion. Legal protection is a protection offered to legal subjects in the form of legal instruments, both preventative and repressive, both unwritten and written. Legal protection describes its lawful purpose, a concept where the law can give justice, order, certainty, benefitand peace. Therefore, there is a need for a true improvementin the service of the national social security system by BPJS Health so that individuals who are not registered with BPJS Health may have solutions in getting legal benefits and justice as a form of implementing state legal protection for their people. Justice is indicated in this context that BPJS Health must give outstanding and good service so that individuals who are notalready registered with BPJS Health will be moved to register because of the huge advantages that will be received. The government obviously cannot appear as if it is hands-off by permitting persons not registered with BPJS Kesehatan to seek treatment in the general patient category constantly, since after all.

\section{Conclusion}

Personal health services are only applicable in legal protection for people who are notenrolled in the BPJS Health social security system. The state does not offer legal protection in the form of duty for delivering health care because individuals who are not enrolled as BPJS Health participants will be registered as general patients, requiring them to pay for treatments individually or through private insurance. While the idea of BPJS Health, as described in the BPJS Law requires everyone to register for BPJS Health, BPJS Health still has significant flaws, which causes some individuals to be hesitant and unwilling to register as BPJS Health participants.

\section{References}

Ernawati, T., \& Uswatul, D. (2019). Hubungan Kepesertaan JKN Mandiri dengan Pendapatan, Pengetahuan, Persepsi, Akses, dan Kepercayaan Masyarakat Suku Sakai di Desa Petani Kecamatan Mandau Kabupaten Bengkalis Tahun 2018. Jurnal Kebijakan Kesehatan Indonesia: JKKI, 8(1).

Hasrul, M. (2017). Penataan Hubungan Kelembagaan Antara Pemerintah Provinsi Dengan Pemerintah Kabupaten/Kota. Jurnal PERSPEKTIF, 22(1).

Humas BPJS Kesehatan. (2013). Sejarah Perjalanan Jaminan Sosial di Indonesia,. Retrieved from BPJS Kesehatan website:https://bpjs-kesehatan.go.id/bpjs/index.php/pages/detail/2013/4

IImar, A. (2014). Membangun Negara Hukum Indonesia. Makassar: Phinatama Media.

Irwansyah. (2020). Penelitian Hukum: Pilihan Metode dan Praktik Penulisan Artikel. Yogyakarta: Mirra Buana Media. 
NKRI. Pasal 1 ayat (1) Undang-Undang Nomor 40 Tahun 2004 Tentang Sistem Jaminan Sosial Nasional. , (2004).

NKRI. Pasal 4 huruf (g) dalam Undang-Undang Nomor 24 Tahun 2011 Tentang Badan Penyelenggara Jaminan Sosial., (2011).

Riatkomo, F. I. (2018). Kesehatan 66 Juta Warga Belum Terlindungi. Retrieved from Kompas.com website: https:/www.kompas.id/baca/utama/2018/04/09/kesehatan-66-juta-warga-belum-terlindungi

Rusyad, Z. (2018). Hukum Perlindungan Pasien (Konsep Perlindungan Hukum Terhadap Pasien Dalam Pemenuhan HakKesehatan Oleh Dokter dan Rumah Sakit). Malang: Setara Pres.

Sudjadi, A., \& Dkk. (2017). Penerapan Pelayanan Kesehatan Masyarakat Miskin Yang Ideal Dalam Pelayanan Kesehatan Masyarakat Miskin Melalui Program Jamkesmas. SOEPRA Jurnal Hukum Kesehatan, 3(1).

Sulastomo. (2011). Sistem Jaminan Sosial Nasional (Mewujudkan Amanat Konstitusi . Jakarta: Buku Kompas.

Tim Kecil Pokja. (2020). Naskah Akademik RUU tentang Sistem Jaminan Sosial Nasional, diakses pada. Retrieved from jamsosindonesia.com website: https://www.jamsosindonesia.com/kjs/files/NARUU BPJS.pdf 